\title{
Blood glucose response to a calamansi drink in healthy adults: a non-randomised study
}

\author{
Angela Siner ${ }^{*}(\mathbb{D}$, Mauna Sree Sevanesan, Tati Ambomai, Zakiah Abd. Wahab and Liwan Lasem
}

\begin{abstract}
Objective: Glycaemic Index (Gl) ranks the body's response to carbohydrate content in food such that high Gl food increases postprandial blood glucose levels. One of the popular drinks at food and beverage outlets is a drink made from calamansi, a citrus that is believed not to induce an increase in blood glucose levels. In this non-randomised single-blind (participants) study, capillary blood from 10 healthy males were sampled following consumption of either glucose or the calamansi drink. The blood glucose measurements were then used to calculate the Gl for the drink.

Results: The Gl of the calamansi drink tested was calculated as 37, a value within the range of low Gl foods.

Trial registration Clinical Trials identifier NCT04462016; Retrospectively registered on July 1, 2020.

Keywords: Calamansi, Glycaemic index, Post-prandial blood glucose
\end{abstract}

\section{Introduction}

Diabetes mellitus is becoming a major public health concern worldwide [1]. Prolonged hyperglycaemia increases the risk of microvascular damage such as neuropathy that contributes to increased macrovascular complications such as ischaemic heart disease and ultimately reduced life expectancy [2]. As diabetics have increased hunger and food intake partly due to accelerated gastric emptying caused by absent or delayed secretion of insulin [3], normalising blood glucose slows its progression and prevents the development of complications [4]. Low glycaemic index (GI) food with a GI of 55 or lower, are slowly absorbed and produces lower peaks in blood glucose, which is useful for maintaining glycaemic control [5]. Decreased rate of glucose absorption reduces postprandial rise in gut hormones such as incretins and insulin by maintaining suppression on free fatty acids (FFA) and counter regulatory responses, while at the same time achieving lower blood glucose concentrations. Over time, glucose is withdrawn from the circulation at a faster rate

\footnotetext{
*Correspondence: sangela@unimas.my
}

Department of Basic Medical Sciences, Faculty of Medicine and Health

Sciences, Universiti Malaysia Sarawak, 94300 Kota Samarahan, Sarawak,

Malaysia such that its levels return to baseline despite continued absorption from the gut [6].

Calamansi, which is also known as "calamondin" in America or "limau kasturi" in Malaysia [7], is consumed by many due to its potential health benefits [8] that includes the potential to lower post-prandial blood glucose [9]. Blood glucose response following consumption of a commercially sold calamansi drink was evaluated in this study. Data from this study will be helpful to consumers making drink choices in view of the increasing number diabetic individuals in the community [10]. Data from this study will also provide baseline information for further community-based investigations related to the GI of other foods.

\section{Main text}

\section{Materials and methods}

This non-randomised, single-blind (participants) study that was based on the report of a joint consultation between the Food and Agriculture Organization (FAO) and World Health Organisation (WHO) [11] was conducted between January and May of 2018 at the teaching laboratory of the Faculty of Medicine and Health Sciences, Universiti Malaysia Sarawak. Consenting 
18 to 19 -year-old males $(\mathrm{n}=16)$ were pre-screened. Although all met the inclusion criteria, 10 were selected by simple randomisation for this two-arm study. All 10 participants were advised to abstain from alcohol and sleep for at least 6-8 h; fast for 8-10 h prior to each test. During each test, participants refrained from any vigorous activity that can alter blood glucose values; drinking water was provided throughout all tests. A total of 4 tests were conducted [11]: three for glucose (i.e., reference drink) and one for calamansi drink (i.e., test drink); tests were conducted within 1-2 weeks after the previous test. Each test lasted for $2 \mathrm{~h}$. The calamansi drink used in this study was obtained from a commercial source (produced and marketed mainly in Sarawak, Malaysia). During the tests, participants were given unmarked drinking containers, in which both drinks had similar odour and appearance. The same 10 participants took part in all 4 tests.

Weight was measured using a digital weighing scale (Guardian Classic Digital Weighing Scale, Malaysia); height measured using a stadiometer (SECA, 213 Hamburg, Germany). The body mass index (BMI) was calculated using the weight (in kilograms) divided by height (in meter squared) formula and interpreted using the standard weight status categories for adults 18 years old and older [12]. Waist circumference [13]; urine dipstick test using Combur-Test ${ }^{\circledR}$ strips (Roche Diagnostics $\mathrm{GmbH}$, Germany); capillary blood glucose levels measured using Accu-Chek ${ }^{\circledR}$ glucometer (Roche, Germany) with finger prick blood obtained using Accu-Chek ${ }^{\circledR}$ lancets (Roche, Germany) were also recorded [14].

Post-prandial blood glucose response measurements were done based on FAO/WHO [11]. Briefly, urine and capillary blood was measured at time " 0 ". The second measurement was taken $30 \mathrm{~min}$ post consumption of the reference drink, $75 \mathrm{~g}$ of glucose (Glucolin ${ }^{\circledR}$, Malaysia) dissolved in $250 \mathrm{~mL}$ of drinking water. Urine and capillary blood were again tested at every 30 -min intervals until the 120 th min. The same procedures were repeated with the test drink, $250 \mathrm{~mL}$ of a commercially sourced calamansi drink.

The incremental area under the curve (IAUC) was used to calculate the area under the curve by applying the trapezoid rule in which the IAUC for the reference drink (glucose) was divided by the IAUC for calamansi followed by multiplication with 100 [11]. When a blood glucose value falls below the baseline, only the area above the fasting level is included and the area of the curve that was beneath the fasting concentration was excluded in the calculation. The following formula was used to calculate the GI [11]: 100 x (IAUC for test drink/IAUC for glucose drink).

\section{Results and discussion}

All 10 participants were 19-year-old males and nonsmokers with mean weight of $64.5 \mathrm{~kg} \pm 8.8$ (standard error, SE); mean height of $169.02 \mathrm{~cm} \pm 5.2$; mean BMI of $22.50 \mathrm{~kg} / \mathrm{m}^{2} \pm 2.0$; mean waist circumference of $77.7 \mathrm{~cm} \pm 7.8$; mean random blood glucose of $4.89 \mathrm{mmol} / \mathrm{L} \pm 0.4$; negative urine dipstick result. The pre-screen ensured the participants were suitable to take part in the study as their BMI was within the ranges of 18.5 to $24.99 \mathrm{~kg} / \mathrm{m}^{2}$ [12]; waist circumference was not more than $102 \mathrm{~cm} \mathrm{[13]} \mathrm{and} \mathrm{random} \mathrm{blood} \mathrm{glucose} \mathrm{were}$ less than $7.8 \mathrm{mmol} / \mathrm{L}$ [2]. None of them were on any medications; none had family history of inherited diseases and none were diagnosed with pre-existing conditions such as human immunodeficiency virus (HIV) infection, hepatitis, inflammatory bowel diseases, diabetes mellitus, heart conditions (angina, arrhythmia or heart failure), kidney disease, blood disorders such as thalassaemia [6]; none had a history of acute medical or surgical event within the past 6 months.

As shown in Fig. 1, post-prandial blood glucose at 30 min after consumption of either reference drink (glucose) or test drink (calamansi) showed that blood glucose peaked at $9 \mathrm{mmol} / \mathrm{L}$ for reference drink (glucose) and $7.9 \mathrm{mmol} / \mathrm{L}$ for test drink (calamansi). This response was similar to studies with coconut water, custard apple, cashew and soursop [15]. At $1 \mathrm{~h}$ post-prandial, blood glucose levels started to decrease $(7.7 \mathrm{mmol} / \mathrm{L}$ for reference drink and $5.5 \mathrm{mmol} / \mathrm{L}$ for test drink) and both returned to baseline at the last blood glucose measurement $(5.6 \mathrm{mmol} / \mathrm{L}$ for reference drink and $4.7 \mathrm{mmol} / \mathrm{L}$ for test drink). This response was the same as those reported in studies testing blood glucose response to fruits such as watermelon, papaya and durian [16]. The decrease in glucose absorption 2-h post prandial is due to counter regulatory by hormones such as insulin and glucagon $[6$,

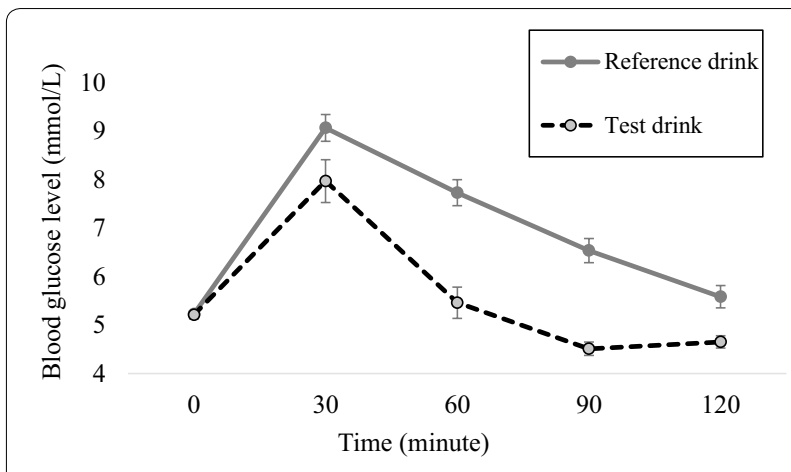

Fig. 1 Post-prandial blood glucose levels following consumption of the reference drink (glucose) or test drink (calamansi). Each point is the average blood glucose from 30 measurements for the reference drink and the average of 10 measurements for the test drink 
17]. The urine dipstick results for all 10 participants were negative at all sampling time points in all of the tests.

The GI for the test drink (calamansi) was estimated as 37, showing that it has a low potential for raising blood glucose levels which can be inferred to cause a similar albeit slightly higher response in a diabetic individual [18, 19]. Food with low GI may slow the rate of gastric emptying as it is associated with prolonged small intestine transit time that reduces postprandial glucose absorption [20, 21]. The acidity contributed by the citric acid and ascorbic acid content in the calamansi drink, could also be a factor as acidity caused delayed gastric emptying [22]. The low GI could also be due to the content of the calamansi drink tested as calamansi fruit skin is rich in flavonoids [23] such as hesperidin and naringin that have been suggested to have hypoglycaemic properties in vitro [24] and in a diabetic rat model [8]. The fruit skin of calamansi also contains pectin, a natural fibre that can decrease the rise in blood glucose levels following a meal by shortening glucose contact time with the absorbing surface [25].

\section{Limitations}

- The sample population. Future studies should also include pre-diabetic individuals and diabetic patients to enable comparison with demographic data.

- The test drink. Although freshly prepared test drink would have been ideal, this was not feasible due to logistical constraints and this led to the choice of a commercially available drink.

- The gender of the study participants. Future research should include both genders so that it is more representative of the general population.

\footnotetext{
Abbreviations

BMI: Body mass index; FAO: Food and Agriculture Organization; FFA: Free fatty acids; GI: Glycaemic index; HIV: Human immunodeficiency virus; IAUC : Incremental area under the curve; SE: Standard error; WHO: World Health Organisation.
}

\section{Acknowledgements}

The authors thank the Faculty of Medicine and Health Sciences, Universiti Malaysia Sarawak for permission to conduct this study. This research was conducted in fulfilment of the Elective 1 research course (MDP20505) requirement for MS, TA \& ZAW (second year, pre-clinical phase undergraduate Medical students).

\section{Declarations}

This manuscript adheres to Consolidated Standards of Reporting Trials (CONSORT) guidelines.

\section{Authors' contributions}

AS conceptualized \& designed the study; supervised data collection, analysis \& interpretation; drafted the manuscript. MS, TA \& ZAW conducted the experiments. LL provided technical support on study design \& assisted in data collection. All authors read and approved the final manuscript.

\section{Funding}

This study was conducted without any specific financial support from a funding agency.

\section{Availability of data and materials}

This could be made available from the corresponding author upon reasonable request.

\section{Ethics approval and consent to participate}

This study was approved by the Research Ethics Committee, Faculty of Medicine and Health Sciences, Universiti Malaysia Sarawak (UNIMAS/NC-21.02/03$02 \mathrm{Jld} .2$ (118)). All participants were given oral and written information on study procedures and risks prior to the start of the study. Informed consent through the completion of consent forms were obtained prior to the prescreen. Only eligible participants, who consented to participate, took part in the subsequent tests. All samples were de-identified at all points of data collection.

\section{Consent for publication}

Not applicable.

\section{Competing interests}

The authors declare that they have no competing interests.

Received: 22 May 2020 Accepted: 21 August 2020

Published online: 28 August 2020

\section{References}

1. Saeedi P, Petersohn I, Salpea P, Malanda B, Karuranga S, Unwin N, et al. Global and regional diabetes prevalence estimates for 2019 and projections for 2030 and 2045: results from the International Diabetes Federation Diabetes Atlas, 9(th) edition. Diabetes Res Clin Pract. 2019;157:107843.

2. World Health Organization. Definition and diagnosis of diabetes mellitus and intermediate hyperglycemia: report of a World Health Organization/ International Diabetes Federation consultation. Geneva: World Health Organization; 2006

3. Aronoff SL, Berkowitz K, Shreiner B, Want L. Glucose metabolism and regulation: beyond insulin and glucagon. Diabetes Spectrum. 2004;17(3):183-90.

4. Thomas D, Elliott EJ. Low glycaemic index, or low glycaemic load, diets for diabetes mellitus. Cochrane Database Syst Rev. 2009;1:CD006296.

5. Marsh K, Barclay A, Colagiuri S, Brand-Miller J. Glycemic index and glycemic load of carbohydrates in the diabetes diet. Curr Diab Rep. 2011;11(2):120-7.

6. Jenkins DJ, Kendall CW, Augustin LS, Franceschi S, Hamidi M, Marchie A et al. Glycemic index: overview of implications in health and disease. Am J Clin Nutr. 2002;76(1):266S-73S.

7. Bin Y, Danping Z, Jingting S, Mun WC, Philip C, Shao QL, et al. Characteristics of calamansi (Citrus microcarpa). Part 2: volatiles, physicochemical properties and non-volatiles in the juice. Food Chem. 2012;134(2):696-703.

8. Morte MYT, Acero LH. Potential of calamansi (Citrofortunella microcarpa) fruit peels extract in lowering the glucose level of streptozotocin induced albino rats (Rattus albus). Int J Food Eng. 2017;1(3):29-34.

9. Abu-gabal NS, Abd-alla HI, Mohamed NZ, Aly HF, Shalaby NMM. Phytophenolics composition, hypolipidemic, hypoglycemic, and antioxidant effects of the leaves of Fortunella japonica (Thunb.) Swingle. Int J Pharm Pharm Sci. 2015;7(12):55-63.

10. Tee ES, Yap RWK. Type 2 diabetes mellitus in Malaysia: current trends and risk factors. Eur J Clin Nutr. 2017;71(7):844-9.

11. Carbohydrates in human nutrition. Report of a Joint Food and Agriculture Organization/World Health Organisation Expert Consultation. Rome; 1998. Report No.: 0254-4725 (Print) 0254-4725 (Linking).

12. Azmi MY Jr, Junidah R, Siti Mariam A, Safiah MY, Fatimah S, Norimah AK, et al. Body mass index (BMI) of adults: findings of the Malaysian Adult Nutrition Survey (MANS). Malays J Nutr. 2009;15(2):97-119. 
13. World Health Organisation. Waist circumference and waist-hip ratio: report of a WHO expert consultation. Geneva: World Health Organisation; 2008.

14. MoH Malaysia. Section 2: screening and diagnosis. 5th ed. Malaysia: Ministry of Health Malaysia; 2015. p. 3-7.

15. Passos TU, Alves H, Sampaio DC, Olganê M, Sabry D, Luisa M, et al. Glycemic index and glycemic load of tropical fruits and the potential risk for chronic diseases. Food Sci Technol Int. 2015;35(1):66-73.

16. Robert SD, Ismail AA, Winn T, Wolever TM. Glycemic index of common Malaysian fruits. Asia Pac J Clin Nutr. 2008;17(1):35-9.

17. Ludwig DS. The glycemic index: physiological mechanisms relating to obesity, diabetes, and cardiovascular disease. JAMA. 2002;287(18):2414-23.

18. Jenkins DJ, Wolever TM, Taylor RH, Ghafari H, Jenkins AL, Barker $\mathrm{H}$, et al. Rate of digestion of foods and postprandial glycaemia in normal and diabetic subjects. Br Med J. 1980;281(6232):14-7.

19. Zafar MI, Mills KE, Zheng J, Regmi A, Hu SQ, Gou L, et al. Low-glycemic index diets as an intervention for diabetes: a systematic review and metaanalysis. Am J Clin Nutr. 2019;110(4):891-902.

20. Delport E. A comparison of the glycemic index (Gl) results obtained from two techniques on a group of healthy and a group of mixed subjects. Pretoria: University Van Pretoria; 2006.
21. Muller M, Canfora EE, Blaak EE. Gastrointestinal transit time, glucose homeostasis and metabolic health: modulation by dietary fibers. Nutrients. 2018;10(3):275.

22. Foster-Powell K, Holt SH, Brand-Miller JC. International table of glycemic index and glycemic load values: 2002. Am J Clin Nutr. 2002;76(1):5-56

23. Lou S-N, Hsu Y-S, Ho C-T. Flavonoid compositions and antioxidant activity of calamondin extracts prepared using different solvents. J Food Drug Anal. 2014;22(3):290-5.

24. Lim SM, Loh SP. In vitro antioxidant capacities and antidiabetic properties of phenolic extracts from selected citrus peels. Int Food Res J. 2016;23(1):211-9.

25. Cherbut $\mathrm{C}$. Role of gastrointestinal motility in the delay of absorption by dietary fibre. Eur J Clin Nutr. 1995;49(Suppl 3):S74-80.

\section{Publisher's Note}

Springer Nature remains neutral with regard to jurisdictional claims in published maps and institutional affiliations.
Ready to submit your research? Choose BMC and benefit from:

- fast, convenient online submission

- thorough peer review by experienced researchers in your field

- rapid publication on acceptance

- support for research data, including large and complex data types

- gold Open Access which fosters wider collaboration and increased citations

- maximum visibility for your research: over 100M website views per year

At BMC, research is always in progress.

Learn more biomedcentral.com/submissions 